\title{
Transfer of resistance determinants from a multi-resistant Staphylococcus aureus isolate
}

\author{
E. E. UDO and W. B. GRUBB \\ School of Medical Technology, Curtin University of Technology, GPO Box U 1987, Perth 6001, Western Australia
}

\begin{abstract}
Summary. The clinical isolate Staphylococcus aureus WBG1024 was resistant to cadmium, benzyl penicillin, kanamycin, neomycin, streptomycin, tetracycline and trimethoprim and harboured a conjugative plasmid pWBG637 (34.5 kb) and non-conjugative plasmids of 23.8, $4 \cdot 4,2.8$ and $1.9 \mathrm{~kb}$. Transduction and mixed-culture transfer experiments demonstrated that the 4.4-kb plasmid (pWBG632) encoded resistance to tetracycline and the $23 \cdot 8-\mathrm{kb}$ plasmid (pWBG628) encoded resistance to cadmium, benzyl penicillin, kanamycin, neomycin and streptomycin. The conjugative plasmid pWBG637 was able to mobilise a further $4 \cdot 4-\mathrm{kb}$ plasmid ( $\mathrm{pWBG633)}$ encoding streptomycin resistance and recombined with the multiresistance plasmid pWBG628 to produce transconjugants of various resistance phenotypes.
\end{abstract}

\section{Introduction}

Plasmid-mediated resistance to antimicrobial agents among pathogenic bacteria constitutes a major clinical and economic problem world-wide. Consequently, antibiotic resistance plasmids have been the subject of extensive genetic and biochemical studies. Plasmid transfer in vitro is used to characterise plasmids and establish the genetics and spread of plasmid-linked resistance genes. In Staphylococcus aureus, resistance can be transferred in vitro by transduction, ${ }^{1}$ mixed-culture transfer (MCT; phagemediated conjugation $)^{2}$ and conjugation. ${ }^{3-6}$ Multiresistant $S$. aureus isolates commonly harbour two or more plasmids that often vary in size and resistance phenotypes. In such circumstances, an effective study of plasmid-linked resistance determinants depends upon the successful transfer of plasmids from resistant isolates to suitably marked sensitive, and plasmidfree, recipients. This paper describes the transfer of resistance determinants from a multi-resistant $S$. aureus isolate WBG1024 by a combination of transduction, MCT and conjugation.

\section{Materials and methods}

\section{Bacterial strains}

The bacterial strains and plasmid are listed in table I.

\section{Media}

Brain Heart Infusion Broth (BHIB), Brain Heart Infusion Agar (BHIA), Trypticase Soy Broth (TSB)

Received 30 Aug. 1990; accepted 4 Dec. 1990. and Mueller Hinton Agar (MHA) were purchased from Gibco Diagnostics (Madison, WI, USA).

\section{Mutation of S. aureus strain WBG6522}

An overnight culture $(10 \mathrm{ml})$ of strain WBG6522 was pelleted by centrifugation and the deposit was spread on to BHIA plates containing rifampicin ( $R f)$ $25 \mathrm{mg} / \mathrm{L}$ and incubated overnight at $37^{\circ} \mathrm{C}$. Colonies were subcultured on to another $\mathrm{Rf}$ plate and incubated at $37^{\circ} \mathrm{C}$. $\mathrm{Rf}$ resistance was confirmed with a $25-\mathrm{mg} \mathrm{Rf}$ disk. The Rf-resistant mutant was then induced to mutate to fusidic acid $(\mathrm{Fa})$ resistance by adding $0.1 \mathrm{ml}$ of ethyl methane sulphonate to $10 \mathrm{ml}$ of a late logphase culture and incubating at $37^{\circ} \mathrm{C}$ for $30 \mathrm{~min}$ with gentle shaking. The culture was washed twice in BHIB, resuspended in $1.0 \mathrm{ml}$ of BHIB, incubated at $37^{\circ} \mathrm{C}$ for $2 \mathrm{~h}$, and $0.1 \mathrm{ml}$ was spread on to a BHIA plate containing Fa $5 \mathrm{mg} / \mathrm{L}$. After incubation overnight at $37^{\circ} \mathrm{C}$, resistant colonies were purified on $\mathrm{Fa}$ plates and resistance to both $\mathrm{Fa}$ and $\mathrm{Rf}$ was confirmed by disk sensitivity tests. This strain was designated WBG6522RF.

\section{Antibiotic susceptibility testing}

This was performed on MHA plates by multipoint replication or with impregnated disks. ${ }^{12,13}$

\section{Loss of resistance at $43 \cdot 5^{\circ} \mathrm{C}$}

This was performed as described previously. ${ }^{12}$

\section{Resistance transfer}

Transduction and MCT were performed as described previously. ${ }^{6}$ Phage 85 of the International Phage Typing Set was used for the transduction 
experiments. Recipient colonies which had received transferred determinants by MCT are referred to as transcipients. Conjugation was performed in the presence of polyethylene glycol $40 \% \mathrm{w} / \mathrm{v}$ as previously described. ${ }^{6}$ Selections were made on BHIA containing the following agents $(\mathrm{mg} / \mathrm{L})$ : kanamycin $(\mathrm{Km}) 75$; streptomycin $(\mathrm{Sm}) 100$; tetracycline (Tc) 5 ; trimethoprim (Tp) 2.5; Fa 5; Rf 25; novobiocin ( $\mathrm{Nb}) 5$; acridine yellow (Ay, Gurr Ltd, London) 8.4; and ethidium bromide (Eb) 120. For benzyl penicillin (Pc), $2 \mathrm{U}$ was used and for cadmium (Cd), $2 \times 10^{-2} \mathrm{M}$.

\section{Plasmid isolation, restriction endonuclease analysis, Southern blotting and DNA hybridisation}

Plasmid DNA was isolated by the cetyltrimethylammonium bromide (CTAB) method, ${ }^{11}$ digested with restriction endonucleases according to the manufacturers' instructions and analysed by agarose- $(0.8 \% \mathrm{w} / \mathrm{v})$ gel electrophoresis in TAE buffer $(1.6 \mathrm{M}$ Tris base, $40 \mathrm{mM}$ edetic acid, $0.8 \mathrm{M}$ sodium acetate, $\mathrm{pH} 7 \cdot 2$ ). Phage $\lambda$ DNA digested with the restriction endonuclease HindIII was used as the mol. wt standard. Undigested plasmids were electrophoresed in TAE buffer in agarose $0.5 \% \mathrm{w} / \mathrm{v}$ and the plasmids of strain $\mathrm{WBG} 4483^{6}$ were used as mol. wt standards. Plasmids to be probed were isolated by the CTAB method, purified by caesium chlorideethidium bromide gradient centrifugation ${ }^{12}$ and digested with the restriction endonuclease HpaII, then electrophoresed and transferred to nitrocellulose filters (BioRad Laboratories) by the method of Southern. ${ }^{14}$

Purified plasmids pWBG637 and pWBG628 were labelled with ${ }^{32} \mathrm{P}$ (dCTP) by nick translation. ${ }^{15}$ The ${ }^{32} \mathrm{P}$-labelled probe was hybridised to blotted DNA at $65^{\circ} \mathrm{C}$. After hybridisation, the filters were subjected to the following washes: twice in $2 \times \mathrm{SSC}(\mathrm{NaCl} 17.5 \mathrm{gm}$; sodium citrate $8.82 \mathrm{gm} ; \mathrm{pH} \mathrm{7.0)}$-sodium dodecyl sulphate (SDS) $0.3 \%$ for $5 \mathrm{~min}$ each; once in $2 \times \mathrm{SSC}-$ SDS $0.1 \%$ for $10 \mathrm{~min}$ and once in $0.2 \times \mathrm{SSC}-\mathrm{SDS} 0.1 \%$ for $10 \mathrm{~min}$; all washes were at room temperature. This was followed by washing in $0.1 \times$ SSC-SDS $0.1 \%$ at $50^{\circ} \mathrm{C}$ for $60 \mathrm{~min}$ and then for $30 \mathrm{~min}$. The filters were then exposed to Kodak X-Omat AR film at $-70^{\circ} \mathrm{C}$ for autoradiography.

\section{Results}

The clinical isolate WBG1024 was resistant to $\mathrm{Cd}$, $\mathrm{Pc}, \mathrm{Km}$, neomycin (Nm), Sm, Tp, Tc, Eb, Ay and susceptible to $\mathrm{Rf}, \mathrm{Fa}, \mathrm{Nb}$, methicillin, gentamicin, erythromycin, spectinomycin, mercury, phenylmercuric acetate, arsenate, and propamidine isethionate (table I). It contained plasmids of $34 \cdot 5,23 \cdot 8,4 \cdot 4,2 \cdot 8$

Table I. $S$. aureus strains and plasmids

\begin{tabular}{|c|c|c|c|}
\hline $\begin{array}{c}\text { Strain } \\
\text { no. }\end{array}$ & Properties & Plasmids, kb & $\begin{array}{l}\text { Reference } \\
\text { no. }\end{array}$ \\
\hline WBG541 & RN450 mutated to chromosomal $\mathrm{Fa}^{\mathrm{R}}, \mathrm{Rf}^{\mathrm{R}}$ & None & 8 \\
\hline WBG879 & WBG541 lysogenised with phage 85 & None & 8,9 \\
\hline WBG742 & RN450 mutated to chromosomal $\mathrm{Nb}^{\mathrm{R}}$ & None & 10 \\
\hline WBG 1876 & WBG541 lysogenised with phage $\mathrm{J}$ & None & 9 \\
\hline WBG4483 & RN450 transductants and transconjugant & $\begin{array}{l}\text { pWBG615, } 40 \cdot 3 \\
\text { pWBG115, } 22 \cdot 5 \\
\text { pWBG3, 4.4 } \\
\text { pE194 3.5 }\end{array}$ & 6 \\
\hline WBG1024 & $\begin{array}{l}\text { Clinical isolate } \\
\mathrm{Pc}^{\mathrm{R}}, \mathrm{Km}^{\mathrm{R}}, \mathrm{Nm}^{\mathrm{R}}, \mathrm{Sm}^{\mathrm{R}}, \mathrm{Tp}^{\mathrm{R}}, \mathrm{Tc}^{\mathrm{R}}, \mathrm{Cd}^{\mathrm{R}}\end{array}$ & $\begin{array}{l}\text { pWBG637, } 34.5 \\
\text { pWBG628, } 23.8 \\
\text { pWBG632, 4.4 } \\
\text { pWBG633, 4.4 } \\
\text { pWBG634, } 2 \cdot 8 \\
\text { pWBG651, } 1.9\end{array}$ & This study, 7 \\
\hline WBG4527 & WBG541 transconjugant, $\mathrm{Sm}^{\mathrm{R}}$ & $\begin{array}{l}\text { pWBG637, } 34 \cdot 5 \\
\text { pWBG633, } 4 \cdot 4\end{array}$ & 7 \\
\hline WBG4856 & WBG 1024 cured of $\mathrm{Km}^{\mathrm{R}}, \mathrm{Nm}^{\mathrm{R}}, \mathrm{Sm}^{\mathrm{R}}$ & $\begin{array}{l}\text { pWBG637, 34.5 } \\
\text { pWBG632, } 4.4 \\
\text { pWBG634, } 2.8 \\
\text { pWBG651, } 1.9\end{array}$ & This study \\
\hline WBG4530 & WBG879 transcipient $\mathrm{Pc}^{\mathrm{R}}, \mathrm{Cd}^{\mathrm{R}}, \mathrm{Km}^{\mathrm{R}}, \mathrm{Nm}^{\mathrm{R}}, \mathrm{Sm}^{\mathrm{R}}$ & pWBG628, 23.8 & This study \\
\hline WBG4844 & WBG879 transcipient $\mathrm{Tc}^{\mathrm{R}}$ & pWBG632, $4 \cdot 4$ & This study \\
\hline WBG6178 & WBG879 transcipient $\mathrm{Ay}^{\mathrm{R}}$ & pWBG634, $2 \cdot 8$ & This study \\
\hline WBG4526 & WBG541 transconjugant $\mathrm{Km}^{\mathrm{R}}, \mathrm{Nm}^{\mathrm{R}}, \mathrm{Sm}^{\mathrm{R}}$ & pWBG629, 39-1 & This study \\
\hline WBG4528 & WBG541 transconjugant $\mathrm{Pc}^{\mathrm{R}}, \mathrm{Km}^{\mathrm{R}}, \mathrm{Nm}^{\mathrm{R}}, \mathrm{Sm}^{\mathrm{R}}$ & pWBG $630,40 \cdot 2$ & This study \\
\hline WBG4529 & $\begin{array}{l}\text { WBG } 541 \text { transconjugant } \mathrm{Pc}^{\mathrm{R}}, \mathrm{Cd}^{\mathrm{R}}, \mathrm{Km}^{\mathrm{R}}, \mathrm{Nm}^{\mathrm{R}} \text {, } \\
\mathrm{Sm}^{\mathrm{R}}\end{array}$ & pWBG631, 53.2 & This study \\
\hline WBG4529A & WBG742 carrying pWBG631 & pWBG631, 53.2 & This study \\
\hline WBG6522 & RN981, $\mathrm{rec}^{-}$ & None & 10 \\
\hline WBG6522RF & WBG5522 mutated to chromosomal $\mathrm{Fa}^{\mathrm{R}}, \mathbf{R f}^{\mathrm{R}}$ & None & This study \\
\hline WBG6522A & $\begin{array}{l}\text { WBG6522 transductants and transconjugants; } \mathrm{Pc}^{\mathrm{R}} \text {, } \\
\mathrm{Cd}^{\mathrm{R}}, \mathrm{Km}^{\mathrm{R}}, \mathrm{Nm}^{\mathrm{R}}, \mathrm{Sm}^{\mathrm{R}}, \mathrm{Tc}^{\mathrm{R}}\end{array}$ & $\begin{array}{l}\text { pWBG637, } 34.5 \\
\text { pWBG628, } 23.8 \\
\text { pWBG3, } 4.4\end{array}$ & This study \\
\hline
\end{tabular}

Ay, acridine yellow; Cd, cadmium; Pc, benzyl penicillin; $\mathrm{Km}$, kanamycin; $\mathrm{Nm}$, neomycin; Sm, streptomycin; Fa, fusidic acid; Rf, rifampicin; Nb, novobiocin; Tc, tetracycline; Tp, trimethoprim; rec ${ }^{-}$, recombination deficient; superscript ${ }^{R}$, resistance. 
and $1.9 \mathrm{~kb}$ (fig. 1) and was lysed by phages $6 / 47 / 54 / 84$ 85 of the International Phage Typing Set.

To determine the resistance phenotypes of the plasmids in isolate, WBG1024, it was used as donor in transduction, MCT and conjugation experiments. Resistance to $\mathrm{Cd}, \mathrm{Ay}, \mathrm{Tc}, \mathrm{Pc}, \mathrm{Km}, \mathrm{Nm}$ and $\mathrm{Sm}$ was transferred by transduction and MCT. Screening of 404 transductants and transcipients revealed that $\mathrm{Tc}$ resistance $\left(\mathrm{Tc}^{\mathrm{R}}\right)$ was not co-transferred with any other phenotype whereas resistance to $\mathrm{Cd}, \mathrm{Pc}, \mathrm{Km}, \mathrm{Nm}$ and Sm were always co-transferred irrespective of whether the selection was with $\mathrm{Km}, \mathrm{Sm}$ or $\mathrm{Cd}$. The transfer of $\mathrm{Tc}^{\mathrm{R}}$ and $\mathrm{Ay}^{\mathrm{R}}$ corresponded to the transfer of a $4 \cdot 4-\mathrm{kb}$ and a $2 \cdot 8-\mathrm{kb}$ plasmids respectively and the transfer of resistance to $\mathrm{Cd}, \mathrm{Pc}, \mathrm{Km}, \mathrm{Nm}$ and $\mathrm{Sm}$ to the transfer of the $23 \cdot 8-\mathrm{kb}$ plasmid pWBG628 (fig. 1). This relationship was further confirmed by curing experiments on isolate WBG1024 and its transductants and transcipients. However, when plasmid pWBG628 was cured from isolate WBG1024, only resistance to $\mathrm{Km}$ and $\mathrm{Nm}$ was lost, indicating that isolate WBG1024 contained additional resistance determinants for $\mathrm{Cd}$, $\mathrm{Pc}$ and $\mathrm{Sm}$.

$\mathrm{Tp}^{\mathrm{R}}$ and $\mathrm{Pc}^{\mathrm{R}}$ were transduced independently and in neither case were plasmids detected in the transductants. No transfer of $\mathrm{Eb}^{\mathrm{R}}$ was obtained by transduction or MCT.

When isolate WBG1024 was examined in conjugation experiments with the standard recipient strain WBG541, transconjugants containing plasmids with

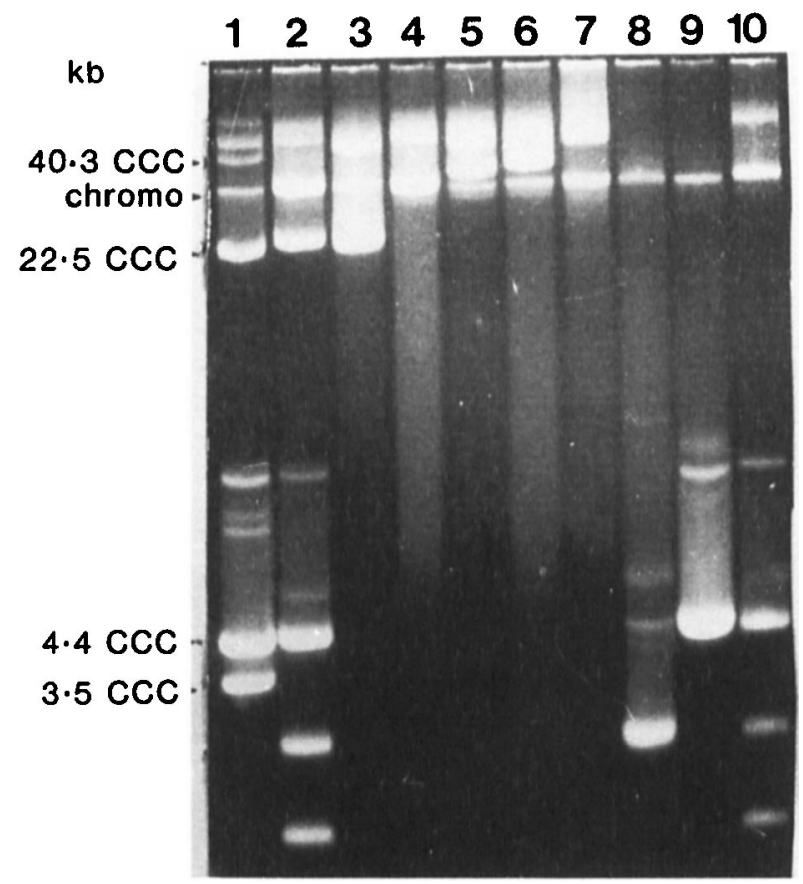

Fig. 1. Plasmids of isolate WBG1024 and its derivatives. Lane 1, WBG4483, plasmid mol. wt markers; 2, WBG1024, pWBG637 (34.5 kb), pWBG628 (23.8 kb), pWBG632/pWBG633 (4.4kb), pWBG634 (2.8 kb), pWBG659 $(1.9 \mathrm{~kb}) ; 3$, pWBG628 Pc $^{\mathrm{R}}$ $\mathrm{Cd}^{\mathrm{R}} \mathrm{Km}^{\mathrm{R}} \mathrm{Nm}^{\mathrm{R}} \mathrm{Sm}^{\mathrm{R}}$ tra ${ }^{-} ; 4$, pWBG637 $\mathrm{tra}^{+}$(34.5 kb); 5, pWBG629 $\mathrm{Km}^{\mathrm{R}} \mathrm{Nm}^{\mathrm{R}} \mathrm{Sm}^{\mathrm{R}}$ tra $^{+}(39.1 \mathrm{~kb}) ; 6$, pWBG630 $\mathrm{Pc}^{\mathrm{R}} \mathrm{Km}^{\mathrm{R}} \mathrm{Nm}^{\mathrm{R}} \mathrm{Sm}^{\mathrm{R}}$ tra $^{+}$ (40.2 kb); 7, pWBG631 $\mathrm{Pc}^{\mathrm{R}} \mathrm{Cd}^{\mathrm{R}} \mathrm{Km}^{\mathrm{R}} \mathrm{Nm}^{\mathrm{R}} \mathrm{Sm}^{\mathrm{R}} \operatorname{tra}^{+}(53.2 \mathrm{~kb}) ; 8$, pWBG634 $\mathrm{Ay}^{\mathrm{R}}(2.8 \mathrm{~kb}) ; 9$, pWBG632 $\mathrm{Tc}^{\mathrm{R}} \mathrm{tra}^{-}(4.4 \mathrm{~kb}) ; 10$, WBG4856, WBG1024 cured of pWBG628. four different resistance phenotypes were obtained (table II). Plasmids of the pWBG631 type encoded resistance to $\mathrm{Cd}, \mathrm{Pc}, \mathrm{Km}, \mathrm{Nm}$, and $\mathrm{Sm}$ and were obtained by selection with $\mathrm{Km}, \mathrm{Cd}$ or $\mathrm{Sm}$. The pWBG630 plasmid type encoded resistance to Pc, $\mathrm{Km}, \mathrm{Nm}$ and $\mathrm{Sm}$ and transconjugants were obtained on $\mathrm{Km}$ and $\mathrm{Sm}$, whereas plasmids of the pWBG629 type encoding resistance to $\mathrm{Km}, \mathrm{Nm}$ and $\mathrm{Sm}$ were obtained only by selection with $\mathrm{Km}$. Transconjugants of the remaining type were obtained only by $\mathrm{Sm}$ selection and these corresponded to the transfer of the 4.4-kb Sm ${ }^{\mathrm{R}}$ plasmid pWBG633 which was mobilised by the conjugative plasmid pWBG637 as previously reported. ${ }^{7}$

Table II. Transconjugants from strains WBG1024/ WBG541

\begin{tabular}{clc}
\hline $\begin{array}{c}\text { Selective } \\
\text { agent }\end{array}$ & \multicolumn{1}{c}{$\begin{array}{c}\text { Resistance } \\
\text { transferred }\end{array}$} & \multicolumn{1}{c}{$\begin{array}{c}\text { Plasmid (kb) } \\
\text { transferred }\end{array}$} \\
\hline $\mathrm{Km}$ & $\mathrm{Km}, \mathrm{Nm}, \mathrm{Sm}$ & $39 \cdot 1, \mathrm{pWBG} 629$ \\
& $\mathrm{Pc}, \mathrm{Km}, \mathrm{Nm}, \mathrm{Sm}$ & $40 \cdot 2, \mathrm{pWBG630}$ \\
& $\mathrm{Pc}, \mathrm{Cd}, \mathrm{Km}, \mathrm{Nm}, \mathrm{Sm}$ & $53 \cdot 2, \mathrm{pWBG631}$ \\
$\mathrm{Cd}$ & $\mathrm{Pc}, \mathrm{Cd}, \mathrm{Km}, \mathrm{Nm}, \mathrm{Sm}$ & $53 \cdot 2, \mathrm{ND}$ \\
$\mathrm{Sm}$ & $\mathrm{Pc}, \mathrm{Km}, \mathrm{Nm}, \mathrm{Sm}$ & $40 \cdot 2, \mathrm{ND}$ \\
& $\mathrm{Pc}, \mathrm{Cd}, \mathrm{Km}, \mathrm{Nm}, \mathrm{Sm}$ & $53 \cdot 2, \mathrm{ND}$ \\
& $\mathrm{Sm}$ & $4 \cdot 4, \mathrm{pWBG633}$ \\
& $\mathrm{Sm}$ & $4 \cdot 4, \mathrm{pWBG633}$ \\
& & $34 \cdot 5, \mathrm{pWBG637}$
\end{tabular}

For abbreviations, see footnote to table I; ND, not designated.

Plasmids pWBG629 $\left(\mathrm{Km}^{\mathrm{R}} \mathrm{Nm}^{\mathrm{R}} \mathrm{Sm}^{\mathrm{R}}\right)$, pWBG630 $\left(\mathrm{Pc}^{\mathrm{R}} \mathrm{Km}^{\mathrm{R}} \mathrm{Nm}^{\mathrm{R}} \mathrm{Sm}^{\mathrm{R}}\right)$ and pWBG631 $\left(\mathrm{Cd}^{\mathrm{R}} \mathrm{Pc}^{\mathrm{R}} \mathrm{Km}-\right.$ ${ }^{R} \mathrm{Nm}^{\mathrm{R}} \mathrm{Sm}^{\mathrm{R}}$ ) were all found to be conjugative when their transconjugant hosts WBG4526, WBG4528 and WBG4529, respectively, were examined in conjugation experiments as donors with WBG742 as recipient and selection made with $\mathrm{Km}$ and $\mathrm{Sm}$. The plasmids transferred to strain WBG742 had the same phenotype and gave the same $E c o$ RI restriction enzyme fragments as the donor plasmids. Plasmid pWBG629 transferred at highest frequency $\left(3.0 \times 10^{-4} /\right.$ donor $)$, then plasmid pWBG630 (2.0 $\times 10^{-6} /$ donor $)$ and plasmid pWBG631 at the lowest frequency $\left(1.6 \times 10^{-7} /\right.$ donor $)$. In a parallel experiment, plasmid pWBG628 was found not to be conjugative when the host strain WBG4530 was mated with strain WBG742.

\section{Restriction endonuclease analysis}

As plasmids pWBG629, pWBG630 and pWBG631 were not detected in the parent isolate WBG1024 (fig. 1) but had the resistance phenotypes of plasmid pWBG628 and were conjugative, they appear to have arisen by recombinations between plasmids pWBG628 and pWBG637 during conjugation. Consequently the plasmids were compared by restriction 
endonuclease analysis. Plasmids pWBG637, pWBG629, pWBG630 and pWBG631 were found to be related when digested with EcoRI (fig. 2). Plasmid pWBG628 was cut only once with EcoRI and, consequently, no relatedness with the other plasmids was evident. However digestion with $\mathrm{HpaII}$ (fig. 3A) and ClaI (not shown) demonstrated that plasmids pWBG637, pWBG629, pWBG630, pWBG631 and pWBG628 shared some restriction fragments.

The relatedness was confirmed by hybridisation experiments. ${ }^{32}$ P-labelled plasmid pWBG637 hybridised with fragments of plasmids pWBG629, pWBG630 and pWBG631 but not against fragments of plasmid pWBG628 (fig. 3B), whereas ${ }^{32} \mathrm{P}$-labelled plasmid pWBG628 hybridised with some fragments of plasmids pWBG629, pWBG630 and pWBG631 but not with plasmid pWBG637 (fig. 3C). These results indicated that although plasmids pWBG637 and pWBG628 had no detectable homology, plasmids pWBG629, pWBG630 and pWBG631 resulted from recombination between them.

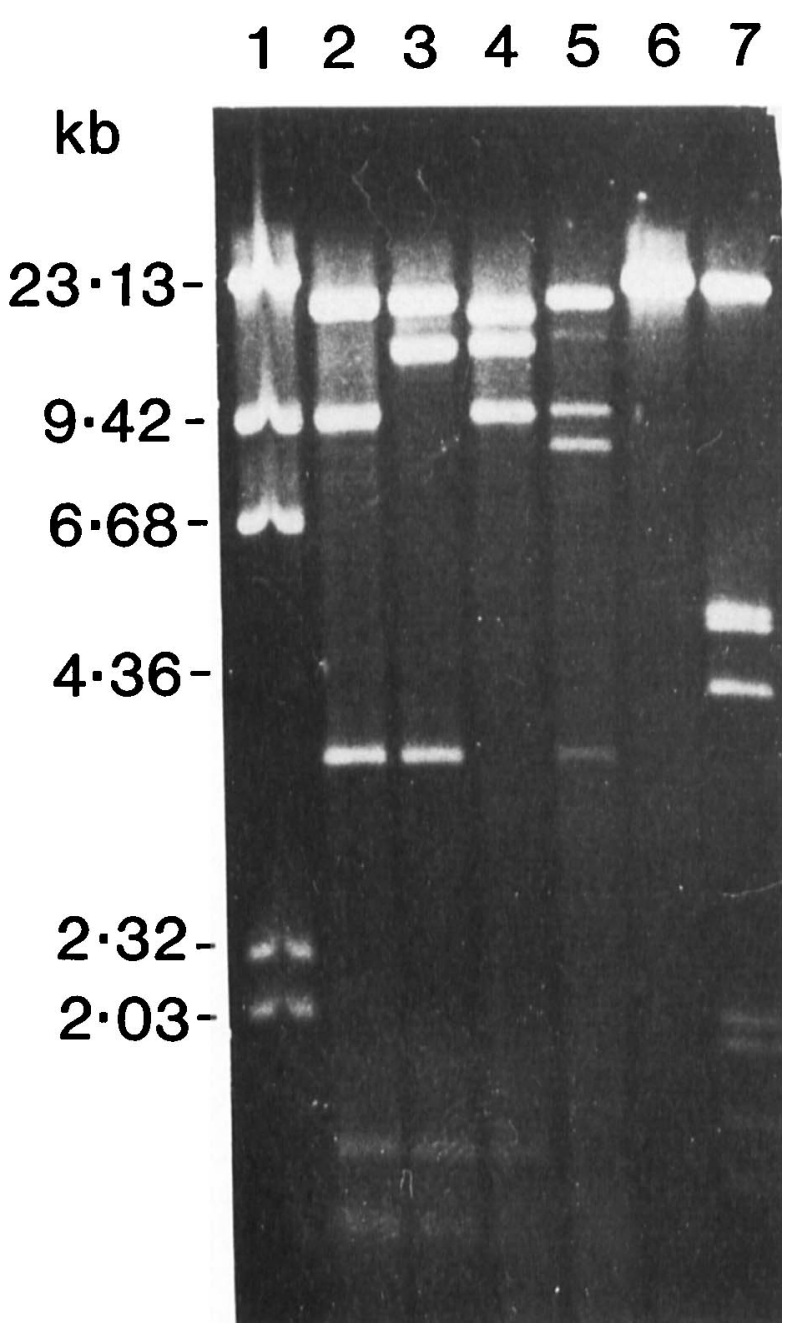

Fig. 2. EcoRI restriction endonuclease analysis of plasmids pWBG637, pWBG628, pWBG629, pWBG630 and pWBG631. Lane 1, phage $\lambda$ DNA digested with HindIII; 2, pWBG637; 3, pWBG629; 4, pWBG630; 5, pWBG631; 6, pWBG628; 7, $\lambda$ DNA digested with HindIII and EcoRI.

\section{Effect of Rec background}

To study how recombination was occurring between plasmids pWBG637 and pWBG628, experiments were conducted in a rec $^{-}$background. Isolate WBG1024 was examined in conjugation experiments with the rec $^{-}$recipient WBG6522RF. All the transconjugants were resistant to $\mathrm{Cd}, \mathrm{Pc}, \mathrm{Km}, \mathrm{Nm}, \mathrm{Sm}$ and harboured single plasmids which varied in size. Analysis of representative plasmids from the transconjugants revealed that they were conjugative and, although closely related, they varied in their EcoRI restriction endonuclease digestion patterns (fig. 4).

In the other experiment, a rec ${ }^{-}$donor WBG6522A was used. This was constructed by first transducing plasmid pWBG628 to strain WBG6522 and then employing this strain as a recipient in a mating with strain WBG4872 (carrying plasmids pWBG637 and pWBG3) and selecting for $\mathrm{Km}$ and Tc resistance. Since plasmid pWBG637 mobilises plasmid pWBG3, ${ }^{7}$ $\mathrm{Tc}^{\mathrm{R}}$ transconjugants were screened by agarose-gel electrophoresis for carriage of plasmids pWBG637, pWBG3 and pWBG628. One such strain (WBG6522A) was then tested for conjugation with strain WBG541, a rec ${ }^{+}$recipient (table III). Transconjugants were obtained only with Tc selection. None of the $\mathrm{Tc}^{\mathrm{R}}$ transconjugants were resistant to $\mathrm{Pc}, \mathrm{Km}$, $\mathrm{Nm}, \mathrm{Sm}$ or $\mathrm{Cd}$.

\section{Behaviour of plasmid pWBG631 in MCT}

Since plasmid pWBG631 $\left(\mathrm{Pc}^{\mathrm{R}} \mathrm{Km}^{\mathrm{R}} \mathrm{Nm}^{\mathrm{R}} \mathrm{Sm}^{\mathrm{R}} \mathrm{Cd}^{\mathrm{R}}\right)$ is conjugative and has the full resistance determinants of plasmid pWBG628, it could be a co-integrate of plasmids pWBG637 and pWBG628. Therefore, it was investigated for its ability to resolve into the component plasmids. Strain WBG4529 (carrying plasmid pWBG631) was grown on antibiotic-free BHIA at $37^{\circ} \mathrm{C}$ and at $43.5^{\circ} \mathrm{C}$, and single colonies were screened for loss of resistance to $\mathrm{Cd}, \mathrm{Pc}, \mathrm{Km}, \mathrm{Nm}$ and $\mathrm{Sm}$. No resistances were lost at $37^{\circ} \mathrm{C}$ but all five resistance determinants were lost together at $43.5^{\circ} \mathrm{C}$ and their loss was accompanied by the loss of plasmid pWBG631, indicating that the resistances were maintained stably on the plasmid. Plasmid pWBG631 was transferred to strain WBG742 by conjugation and one of the transconjugants (WBG4529A) was used as donor in a MCT experiment with strain WBG1876 (table IV). Transcipients obtained by $\mathrm{Km}$ and $\mathrm{Sm}$ selection were all resistant to $\mathrm{Cd}, \mathrm{Pc}, \mathrm{Km}, \mathrm{Nm}$ and $\mathrm{Sm}$. Two types of resistance phenotype were obtained by $\mathrm{Cd}$ selection. One type was resistant to $\mathrm{Cd}, \mathrm{Pc}$, $\mathrm{Km}, \mathrm{Nm}$ and $\mathrm{Sm}$ and the other to $\mathrm{Pc}$ and $\mathrm{Cd}$. Transcipients of the $\mathrm{Cd}^{\mathrm{R}} \mathrm{Pc}^{\mathrm{R}} \mathrm{Km}^{\mathrm{R}} \mathrm{Nm}^{\mathrm{R}} \mathrm{Sm}^{\mathrm{R}}$ phenotype carried plasmids of the same size irrespective of their selection. EcoRI digestion of representative plasmids such as pWBG680 produced the same EcoRI restriction endonuclease digestion fragments and were different from EcoRI fragments of the $\mathrm{Pc}^{\mathrm{R}} \mathrm{Cd}^{\mathrm{R}}$ plasmids such as pWBG681 (fig. 5). 


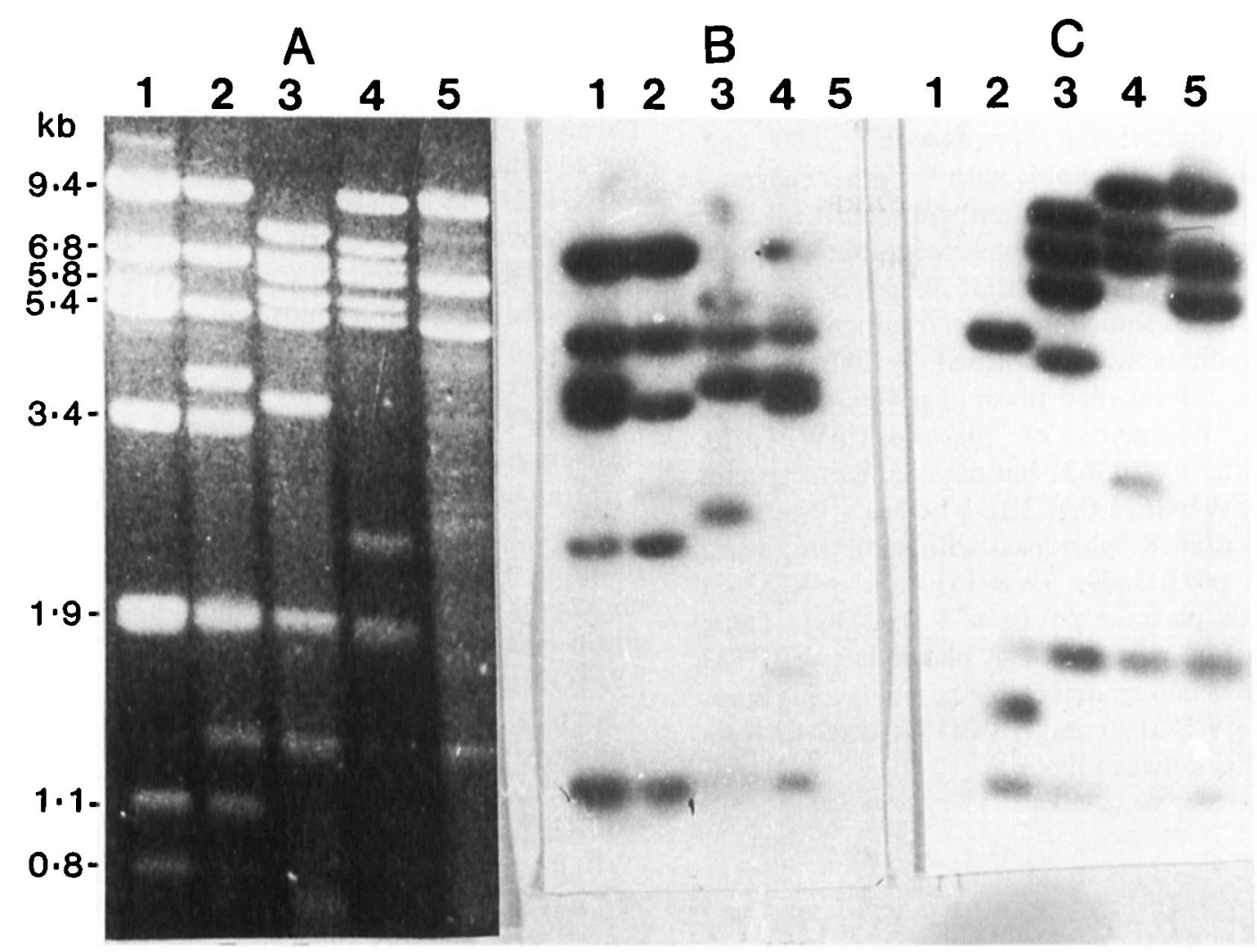

Fig. 3. DNA-DNA hybridisation analysis. (A), HpaII restriction digest of plasmids. Lane 1, pWBG637; 2, pWBG629; 3, pWBG630; 4, pWBG631; 5, pWBG628. (B) Autoradiograph of gel in panel A after Southern transfer and hybridisation with ${ }^{32} \mathrm{P}$-labelled plasmid pWBG637 as probe. No hybridisation was detected with plasmid pWBG628 (lane 5). (C) Autoradiograph of gel in panel A after Southern transfer and hybridisation with ${ }^{32} \mathrm{P}$-labelled plasmid pWBG638 as probe. No hybridisation was detected with plasmid pWBG637 (lane 1).

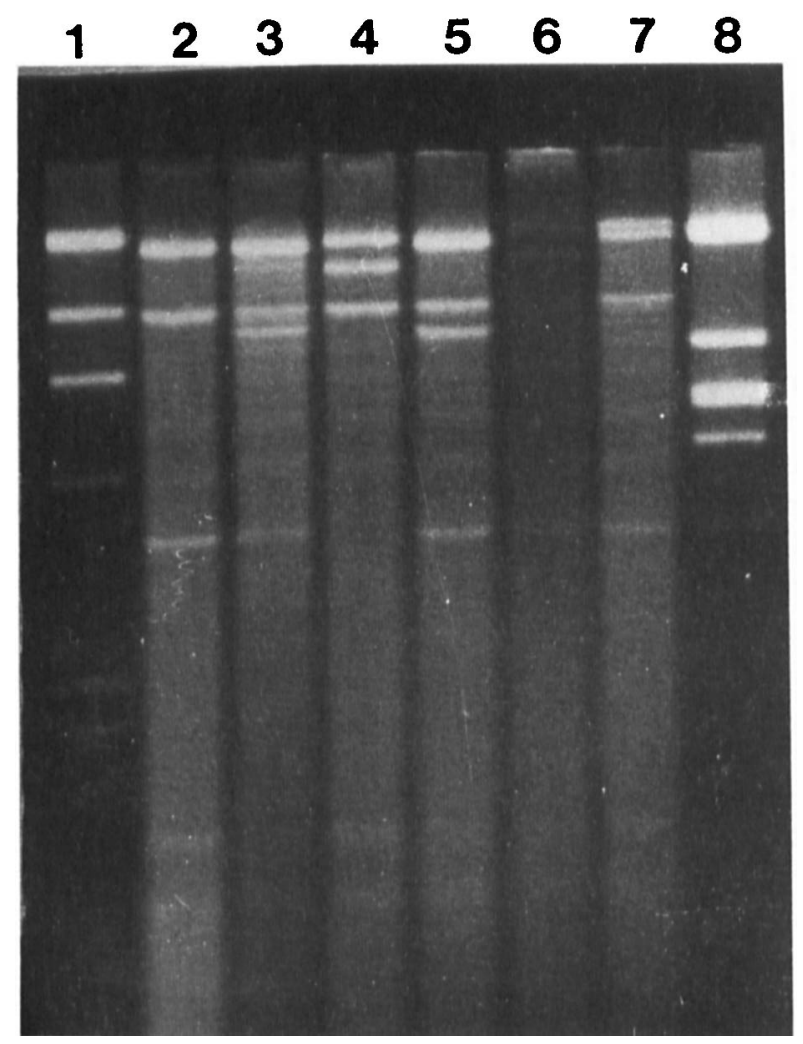

Fig. 4. EcoRI restriction endonuclease analysis of WBG1024/ WBG6522RF transconjugants. Lanes 1 and 8 , phage $\lambda$ DNA digested with HindIII and EcoRI respectively; 2, pWBG637; 3-7, different $\mathrm{Pc}^{\mathrm{R}} \mathrm{Cd}^{\mathrm{R}} \mathrm{Km}^{\mathrm{R}} \mathrm{Nm}^{\mathrm{R}} \mathrm{Sm}^{\mathrm{R}}$ plasmids.

\section{Discussion}

The clinical isolate, $S$. aureus WBG1024 has been analysed for susceptibility to antimicrobial agents, plasmid content and transfer of resistance determinants. Results of curing and transfer experiments indicate that only $\mathrm{Tp}^{\mathrm{R}}$ and $\mathrm{Eb}^{\mathrm{R}}$ did not have a plasmid location.

Isolate WBG1024 harbours six plasmids; two of these, pWBG632 $\left(\mathrm{Tc}^{\mathrm{R}}\right)$ and pWBG633 $\left(\mathrm{Sm}^{\mathrm{R}}\right)$ have the same molecular size $(4.4 \mathrm{~kb})$ and could not be distinguished on agarose gel- electrophoresis of plasmid DNA from isolate WBG1024. However, transfer experiments clearly demonstrated their separate existence in isolate WBG1024. Whe eas plasmid pWBG632 was transferred by transduction and MCT, it was not mobilised by the conjugative plasmid pWBG637, although plasmid pWBG637 does mobilise another $\mathrm{Tc}^{\mathrm{R}}$ plasmid, pWBG3. ${ }^{7}$ On the other hand, plasmid pWBG633 was mobilised by plasmid pWBG637 during conjugation but was not transferred by transduction or MCT. The results of curing, transduction and MCT experiments demonstrated that a separate $\mathrm{Sm}^{\mathrm{R}}$ determinant was borne, together with $\mathrm{Cd}, \mathrm{Pc}, \mathrm{Km}$ and $\mathrm{Nm}$ resistances, on plasmid pWBG628. The resistance phenotype of plasmid pWBG628 is similar to that of a plasmid reported by Lacey. ${ }^{16}$ However, unlike this plasmid, ${ }^{16}$ the 
Table III. Effect of Rec background on recombination

\begin{tabular}{|c|c|c|c|c|}
\hline $\begin{array}{c}\text { Donor } \\
\text { strain no. }\end{array}$ & $\begin{array}{l}\text { Recipient } \\
\text { strain no. }\end{array}$ & $\begin{array}{l}\text { Selective } \\
\text { agent }\end{array}$ & $\begin{array}{l}\text { Resistance } \\
\text { transferred }\end{array}$ & $\begin{array}{l}\text { Plasmid } \\
\text { (kb) }\end{array}$ \\
\hline $\begin{array}{l}\text { WBG1024 } \\
\text { WBG6522A } \\
\left(\mathrm{rec}^{-}\right)\end{array}$ & $\begin{array}{l}\text { WBG6522RF } \\
\left(\text { rec }^{-}\right) \\
\text {WBG541 }\end{array}$ & $\begin{array}{l}\mathrm{Km} \\
\mathrm{Sm} \\
\mathrm{Km} \\
\mathrm{Sm} \\
\mathrm{Tc}\end{array}$ & $\begin{array}{l}\mathrm{Pc}, \mathrm{Cd}, \mathrm{Km}, \mathrm{Nm}, \mathrm{Sm} \\
\text { Pc, Cd, Km, Nm, Sm } \\
\text { Nil } \\
\text { Nil } \\
\text { Tc }\end{array}$ & $\begin{array}{l}\text { c. } 53 \cdot 0^{*} \\
\text { c. } 53 \cdot 0^{*} \\
\text { Nil } \\
\text { Nil } \\
4 \cdot 4, \text { pWBG3 }\end{array}$ \\
\hline
\end{tabular}

*Transconjugants harboured plasmids of slightly different molecular sizes (see also fig. 4).

Table IV. Analysis of WBG4529A/WBG1876 transcipients

\begin{tabular}{cll}
\hline $\begin{array}{c}\text { Selective } \\
\text { agent }\end{array}$ & \multicolumn{1}{c}{$\begin{array}{c}\text { Resistance } \\
\text { transferred }\end{array}$} & Plasmid (kb) \\
\hline Km & Pc, Cd, Km, Nm, Sm & pWBG680, 40.2 \\
Sm & Pc, Cd, Km, Nm, Sm & pWBG680, 40.2 \\
Cd & Pc, Cd, Km, Nm, Sm & pWBG680, 40.2 \\
& Pc, Cd & pWBG681, 36.1 \\
\hline
\end{tabular}

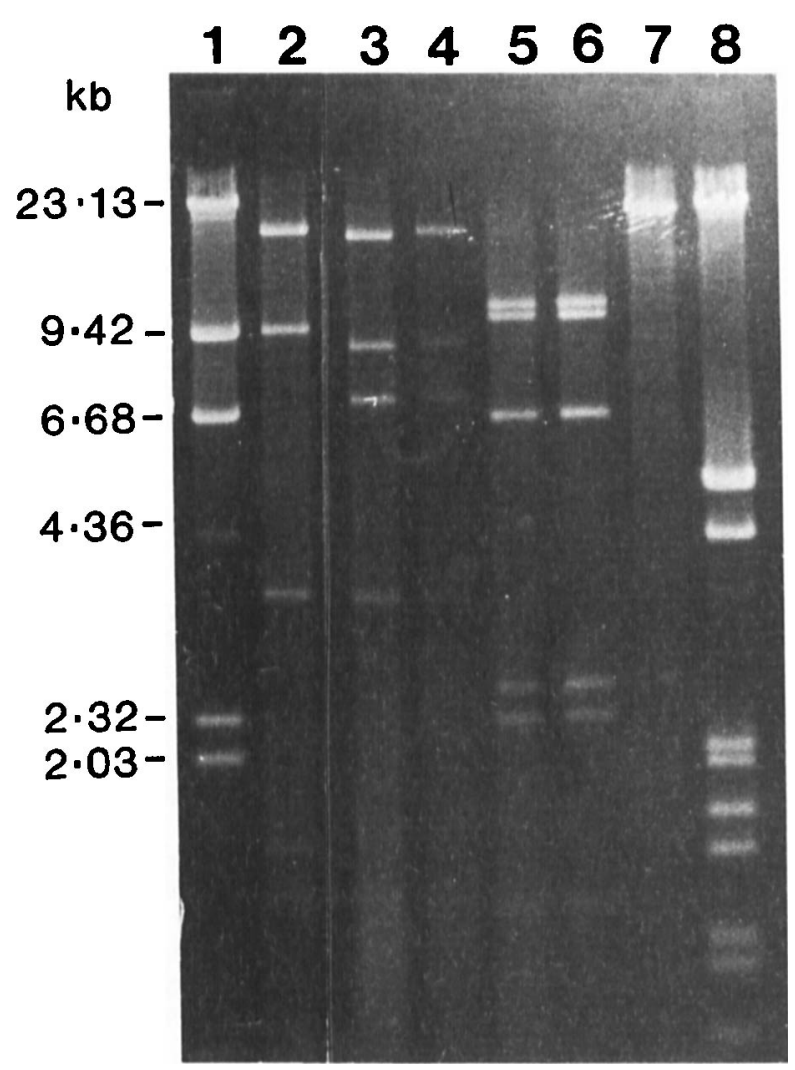

Fig. 5. EcoRI restriction endonuclease analysis of WBG4529A/ WBG1876 transcipients. Lane 1, phage $\lambda$ DNA digested with HindIII ; 2, pWBG637;3 and 4, pWBG680 $\left(\mathrm{Pc}^{\mathrm{R}} \mathrm{Cd}^{\mathrm{R}} \mathrm{Km}^{\mathrm{R}} \mathrm{Nm}^{\mathrm{R}} \mathrm{Sm}^{\mathrm{R}}\right)$; 5 and 6, pWBG681 $\left(\mathrm{Pc}^{\mathrm{R}} \mathrm{Cd}^{\mathrm{R}}\right) 7$, pWBG628; 8, $\lambda$ DNA digested with HindIII and EcoRI.
$\mathrm{Km}^{\mathrm{R}} \mathrm{Nm}^{\mathrm{R}} \mathrm{Sm}^{\mathrm{R}}$ determinants of plasmid pWBG628 were not observed to have a chromosomal location.

It appears that isolate WBG1024 carries two sets of genes encoding resistance to $\mathrm{Pc}$ and $\mathrm{Cd}$. Derivatives of isolate WBG1024 that had lost plasmid pWBG628 after growth at $43.5^{\circ} \mathrm{C}$ were still resistant to $\mathrm{Pc}$ and $\mathrm{Cd}$. These determinants could be different from those of plasmid pWBG628 or they could be the same, and their duplication could be a result of transposition. $\mathrm{Pc}^{\mathrm{R}}$ transposons are well documented in $S$. aureus ${ }^{17-}$ ${ }^{20}$ although there has been no report of $\mathrm{Cd}$ transposition. $\mathrm{Pc}^{\mathrm{R}}$ and $\mathrm{Cd}^{\mathrm{R}}$ appear not to be closely linked because $\mathrm{Pc}^{\mathrm{R}}$ could be transduced without $\mathrm{Cd}^{\mathrm{R}}$ and transconjugants were obtained (e.g., with plasmid pWBG630) which did not carry $\mathrm{Cd}^{\mathrm{R}}$ but encoded the other resistance determinants of plasmid pWBG628. Isolate WBG1024 could, therefore, carry separate transposons for $\mathrm{Pc}^{\mathrm{R}}$ and $\mathrm{Cd}^{\mathrm{R}}$.

The conjugative plasmid pWBG637 mediated transfer of non-conjugative plasmids in two ways: (i) mobilisation of the $\mathrm{Sm}^{\mathrm{R}}$ plasmid, pWBG633, and (ii) recombination with plasmid pWBG628 to form new conjugative resistance plasmids such as pWBG629, pWBG630 and pWBG631. Although mobilisation is well documented ${ }^{3-7,21,22}$ there has been no previous report of recombination similar to that observed between plasmids pWBG637 and pWBG628 in $S$. aureus.

No homology was detected between plasmids pWBG637 and pWBG628. However, this does not exclude the possibility that recombination may occur between short regions (RS) of complementary DNA ${ }^{23}$ not detected in Southern hybridisation experiments. The failure to obtain recombinants when a $\mathrm{rec}^{-}$strain was used as donor in conjugation experiments suggests that some Rec-mediated homologous recombination may be occurring. Non-homologous recombination is usually mediated by transposable elements. ${ }^{24,}{ }^{25} \mathrm{~A}$ feature of transposon-mediated recombination and that involving RS sequences is the formation of cointegrates ${ }^{23-25}$ which may resolve into component parts. Plasmid pWBG631 appeared to be a cointegrate of plasmids pWBG637 and pWBG628 but no resolution of the plasmid was detected when the transconjugants were grown without selective pressure and plasmid pWBG631 and all its resistance determi- 
nants were lost together in curing experiments. Although two different plasmids resulted from MCT of plasmid pWBG631, these plasmids differed from plasmids pWBG628 and pWBG637 in their EcoRI restriction endonuclease digest fragments and it appears that they resulted from the constrains of packaging a $c .53-\mathrm{kb}$ plasmid by phages rather than co-integrate resolution.

Iordanescu ${ }^{26,27}$ and Novick et al. ${ }^{28}$ have observed recombination between compatible staphylococcal plasmids during transduction. However, recombinations between plasmids pWBG628 and pWBG637 were detected only in conjugation and not in transduction or MCT experiments. Of 404 transcipients and transductants tested, in none had any of the resistance determinants of plasmid pWBG628 been deleted. Furthermore, all the transductants and transcipients analysed for plasmids carried single plasmids of the same size as seen in isolate WBG1024. Recombination can occur between incompatible plasmids when a cell is forced to maintain them. ${ }^{29}$ However, plasmids pWBG628 and pWBG637 are compatible and are stably maintained in isolate WBG1024, which eliminates incompatibility as the mitigating factor in their recombination.

Although recombination was observed only from a $\mathrm{rec}^{+}$donor, conjugation occurred from both $\mathrm{rec}^{+}$and $\mathrm{rec}^{-}$donors indicating that conjugation occurs independently of the host's rec status. A similar observation has been reported by El Sohl et al. ${ }^{30}$

Although plasmids pWBG637 and pWBG628 have not been demonstrated to share homologous sequences, it is clear that the rec system is necessary for the observed recombination. This does not exclude any transposition events but so far there is no evidence for the presence of transposons and no recombination occurred in a rec- background. The role of this kind of recombination in the evolution of resistance plasmids deserves further study.

The clinical significance of the conjugative plasmid pWBG637 is its ability to enhance the spread of resistance plasmids by mobilisation ${ }^{7}$ and, as demonstrated in this study, by recombining with plasmids such as pWBG628 to generate new resistance plasmids. This has provided an insight into the evolution and spread of resistance plasmids. So far, no other role has been determined for plasmid pWBG637. However it may have other yet undetermined functions to warrant its carriage in the cell.

This work was supported by a NH\&MRC grant to WBG and a Curtin University of Technology research scholarship to EEU. We are grateful to the State Health Laboratory Service for phage typing.

\section{References}

1. Ritz HL, Baldwin JN. Induction of penicillinase production in staphylococci by bacteriophage. Bacteriol Proc 1958; 58: 40.

2. Lacey RW. Evidence for two mechanisms of plasmid transfer in mixed cultures of Staphylococcus aureus. J Gen Microbiol $1980 ; 119$ : $423-435$.

3. Archer GL, Johnston JL. Self-transmissible plasmids in staphylococci that encode resistance to aminoglycosides. Antimicrob Agents Chemother 1983; 24: 70-77.

4. Forbes BA, Schaberg DR. Transfer of resistance plasmids from Staphylococcus epidermidis to Staphylococcus aureus: evidence for conjugative exchange of resistance. $J$ Bacteriol $1983 ; 153: 627-634$.

5. McDonnell RW, Sweeney HM, Cohen S. Conjugational transfer of gentamicin resistance plasmids intra- and interspecifically in Staphylococcus aureus and Staphylococcus epidermidis. Antimicrob Agents Chemother 1983; 23: 151-160.

6. Townsend DE, Bolton S, Ashdown N, Grubb WB. Transfer of plasmid-borne aminoglycoside-resistance determinants in staphylococci. J Med Microbiol 1985; 20 : 169-185.

7. Udo E, Townsend DE, Grubb WB. A conjugative staphylococcal plasmid with no resistance phenotype. FEMS Microbiol Lett $1987 ; 40$ : 279-283.

8. Townsend DE, Grubb WB, Ashdown N. Gentamicin resistance in methicillin-resistant Staphylococcus aureus. Pathology $1983 ; 15$ : $169-174$.

9. Townsend DE, Ashdown N, Greed LC, Grubb WB. Transposition of gentamicin resistance to staphylococcal plasmids encoding resistance to cationic agents. $J$ Antimicrob Chemother 1984; 14: 115-124.

10. Townsend DE, Bolton S, Ashdown N, Annear DI, Grubb WB. Conjugative, staphylococcal plasmids carrying hitch-hiking transposons similar to Tn554: intra- and interspecies dissemination of erythromycin resistance. Aust J Exp Biol Med Sci 1986; 64: 367-379.

11. Townsend DE, Ashdown N, Bolton S, Grubb WB. The use of cetyltrimethylammonium bromide for the rapid isolation from Staphylococcus aureus of relaxable and non-relaxable plasmid DNA for in vitro manipulation. Lett Appl Microbiol $1985 ; 1: 87-94$

12. Udo EE, Grubb WB. A new class of conjugative plasmid in Staphylococcus aureus. J Med Microbiol 1990; 31 : 207-212.

13. Grubb WB, Annear DI. Unstable drug resistance in Staphylococcus aureus M4. Genet Res 1981 ; 38: 217-223.

14. Southern EM. Detection of specific sequences among DNA fragments separated by gel electrophoresis. $J \mathrm{Mol} B i o l$ 1975; 98 : 503-517.

15. Maniatis T, Fritsch EF, Sambrook J. Molecular cloning: a laboratory manual. Cold Spring Harbor, NY, Cold Spring Harbor Laboratory. 1982

16. Lacey RW. Properties of an unusual genetic element in Staphylococcus aureus. J Med Microbiol 1979; 12:311-319.

17. Kigbo EP, Townsend DE, Ashdown N, Grubb WB. Transposition of penicillinase determinants in methicillin-resistant Staphylococcus aureus. FEMS Microbiol Lett 1985; 28 : 39 43.

18. Weber DA, Goering RV. Tn4201, a $\beta$-lactamase transposon in Staphylococcus aureus. Antimicrob Agents Chemother 1988 . 32: 1164-1169.

19. Shalita Z, Murphy E, Novick RP. Penicillinase plasmids of Staphylococcus aureus. Structural and evolutionary relationships. Plasmid 1980; 3: 291-311.

20. Skurray RA, Rouch DA, Lyon BR et al. Multiresistant Staphylococcus aureus: genetics and evolution of epidemic Australian strains. $J$ Antimicrob Chemother 1988; 21 Suppl C: $19-38$.

21. Projan SJ, Archer GL. Mobilisation of the relaxable Staphylococcus aureus plasmid pC221 by the conjugative plasmid pG01 involves three pC221 loci. J Bacteriol 1989; 171: 1841-1845.

22. Goering RV, Asch DK. Plasmid mobilisation effected by a conjugal aminoglycoside resistance plasmid in Staphylococ- 
cus aureus. Zentralbl Backteriol Parasitenkd Infektionskr Hyg 1985; Abt 1 Suppl 14: 563-565.

23. Novick RP, Projan SJ, Rosenblum W, Edelman I. Staphylococcal plasmid cointegrates are formed by host- and phagemediated general rec systems that act on short regions of homology. Mol Gen Genet 1984; 195 : 374-377.

24. Calos MP, Miller JH. Transposable elements. Cell 1980; 20 : 579-595.

25. Cohen SN, Shapiro JA. Transposable genetic elements. Sci Am $1980 ; 242.2: 36-45$.

26. Iordănescu S. Recombinant plasmid obtained from two different, compatible staphylococcal plasmids. J Bacteriol 1975; 124: $597-601$.
27. Iordănescu S. Relationships between cotransducible plasmids in Staphylococcus aureus. J Bacteriol 1977; 129: 71-75.

28. Novick RP, Iordănescu S, Surdeanu M, Edelman I. Transduction-related cointegrate formation between staphylococcal plasmids: a new type of site-specific recombination. Plasmid 1981; 6: 159-172.

29. Anderson ES. Recombination between unrelated bacterial plasmids. Annal Microbiol (Inst Past) 1974; 125A : 251-259.

30. El Sohl N, Allignet J, Bismuth R, Buret B, Fouace J-M. Conjugative transfer of staphylococcal antibiotic resistance markers in the absence of detectable plasmid DNA. Antimicrob Agents Chemother 1986; 30: 161-169. 